\title{
Modeling Groundwater Contamination Transport for the Hanford Environmental Disposal Facility
}

\author{
S. H. Finfrock
}

Date Published

October 1994

To Be Presented at Math and Comp Topical Meeting Portland, Oregon April 30 - May 4, 1995

Prepared for the U.S. Department of Energy Office of Environmental Restoration and Waste Management

\section{(20) Westinghouse $x_{990}$ Hanford Company Richand, Wastingon}

Hanford Operations and Engineering Contractor for the U.S. Department of Energy under Contract DE-AC06-87RL10930

Copyright Licenes By woeptance of this article, the publisher and/or recipient acknowledges the U.S. Govenment's right to netin a nonerclusive, noyshy-free license in and to any copyright covering this peper. 
LEGAL DSCLAMMER

This report was prepared as an account of work sponsored by an agency of the United States Government. Neither the United States Govemment nor any agency thereof, nor any of their employees, nor any of their contractors, subcontractors or their employees, makes any warranty, express or implied, or assumes any legal liability or responsibility for the accuracy, completeness, or any thind party's use or the results of ach use of any information, apparatus, proctuct, $\alpha$ process disclosed, or represents that its use would not infringe privately owned rights. Reference berein to any specific commercial product, process, or service by trade name, trademark, manufacturer, or otherwise, does not necessarily constitute or imply its endorsement, recommendation, or favoring by the United States Government or any agency thereof or its contractors or subcontractors. The views and opinions of authors expressed herein do not necessarily state or reflect those of the United States Government or any agency thereof.

This report has been reproduced from the best available copy.

Printed in the United States of America

DISCLM-2.CHP (1-91) 


\section{DISCLAIMER}

Portions of this document may be illegible in electronic image products. Images are produced from the best available original document. 


\title{
MODELING GROUNDWATER CONTAMINATION TRANSPORT FOR THE HANFORD ENVIRONMENTAL DISPOSAL FACILITY
}

\author{
Scott Finfrock, Allen Lu, and Truc De Lorenzo \\ West inghouse Hanford Company \\ Post Office Box 1970 \\ Richland, Washington 99352 \\ (509) 376-4078
}

\section{ABSTRACT}

Preliminary groundwater analyses were performed for the Hanford Environmental Restoration Disposal Facility (ERDF) to demonstrate compliance with dose limit performance objectives in DOE Order 5820.2A. ${ }^{1}$ These analyses were designed to determine peak radionuclide concentrations in a theoretical drinking-water well $100 \mathrm{~m}$ downstream from the facility. The resulting peak concentrations can be used to determine inventory limits for the facility.

\section{INTRODUCTION}

The Hanford ERDF, scheduled for construction during 1995, is a low-level waste disposal site that will be capable of holding almost 22,000,000 $\mathrm{m}^{3}$ of waste. While the radionuclide concentration in this facility will be low and water infiltration slight, the potentially large volume could, in combination with excessive concentrations, result in the release of a contaminant plume of some significance relative to established dose limit performance objectives in DOE Order 5820.2A. The resulting contaminant plume could eventually reach the unconfined aquifer beneath the site and could lead to offsite exposures through the use of water drawn from the aquifer or the Columbia River. Therefore, it is necessary to evaluate the potential extent of groundwater contamination and subsequent dose to a downstream user of the groundwater. The results of this evaluation can be used to establish inventory limits and waste form requirements, as needed. Modeling the transport processes can define the relationship between the trench inventory and the peak concentration in the aquifer. Because the most restrictive regulatory limits typically are those that apply to a drinking-water well $100 \mathrm{~m}$ downstream from the waste trench, it is necessary to determine the rate at which contaminants migrate from the trench to the aquifer and the degree of dilution that takes place in the aquifer. In order to do this four things are necessary: a site characterization (e.g., soil parameters), a velocity-vector field for water flowing down from the surface to the aquifer and in the aquifer itself, a release rate for contaminants from the trench, and a transport rate for the movement of contaminants through the vadose zone and aquifer. This paper will describe the steps involved in modeling this process for the ERDF. 


\section{METHODS}

Modeling contaminant movement through the vadose zone and the unconfined aquifer beneath the Hanford Site requires a sophisticated, two- or three-dimensional, finite-element code capable of representing moisture movement and solute transport in variably saturated porous media. The code chosen for this project was VAM3DCG ${ }^{2}$ version 3.1 .

VAM3DCG requires that a three-imensional mesh structure be developed that represents the region to be modeled. The mesh consists of a number of threedimensional elements, each of which is defined by eight node points. These elements need not be regular; however there is a certain degree of error associated with nonorthogonal elements.

For each element and each node, VAM3DCG requires input based on site characteristics, in particular, boundary conditions, initial conditions, and parameters in the transport equations. Nodal boundary conditions required for this problem are the surface fluid flux (resulting from precipitation), the prescribed pressure head values (which define the depth and gradient of the aquifer), and the mass flux on the surface (which is defined as the bottom of the trench). Initial conditions are the soil saturations, pressure-heads, and initial waste concentrations in the soil under the trench. The other required parameters are mostly soil characteristics, including the saturated hydraulic conductivity, specific storage, saturated water content, residual saturation, dispersivity, porosity, and density.

Once the appropriate material properties and boundary conditions have been assigned, the next step is to calculate the flow field that will be in effect beneath the trench. To do this, VAM3DCG takes the nodal boundary conditions (surface recharge and pressure-head gradient in the aquifer region) and solves the governing equations for variably saturated flow. The result of this calculation is a steady-state vector field of Darcy velocities for the entire model.

After the velocity field has been established, the material transport equations can be solved. An essential input to this, along with the velocity field, is the contaminant source term. This typically takes the form of a time-dependent material flux from the bottom of the trench. To determine this release rate a simple onedimensional model of the trench was used. In most cases this was an advectiondominated model.

The advection-dominated release model is used to simulate the processes of release from unstabilized waste. For unstabilized waste, the radionuclides exit the facility at a rate determined by the flow of water and the amount of dispersion (mixing) in the disposal unit (i.e., by near-field transport processes). The mixing-cell cascade model ${ }^{3}$ used here is based on the dispersion analysis of chemical reactors and allows the analysis to incorporate the effects of dispersion in the trench in a simplified manner. In this model, the disposal unit is considered to be composed of a cascade of $\mathrm{N}$ equally sized, well-stirred cells in series. The total volume of the $\mathrm{N}$ cells is equal to the volume of the disposal unit.

The mixing-cell cascade model for $\mathrm{N}$ equally sized cells is described by the following equation: ${ }^{3}$ 


$$
Q(t)=V A C_{0} e^{-\alpha N t} \sum_{n=1}^{N} \frac{\left(\alpha N t^{n-1}\right.}{(n-1) !}
$$

where:

$$
\begin{aligned}
& Q=\text { Release rate ( } \mathrm{Ci} / \mathrm{yr}) \\
& V=\text { Vertical Darcy velocity } \\
& A=\text { Horizontal (planar) area of the disposal unit } \\
& \alpha=V / \theta \text { L } \\
& \theta=\text { Moisture content in the trench } \\
& L=\text { Vertical depth of the disposal unit } \\
& R=\text { Retardation factor in the disposal unit. }
\end{aligned}
$$

The initial concentration of contaminants in the interstitial water can be determined from the following equation: ${ }^{3}$

$$
C_{0}=\frac{m}{\theta V R}
$$

where:

$$
\begin{aligned}
& m=\text { Total facility inventory of the radionuclides in the disposal unit } \\
& V=\text { Total volume of the disposal unit. }
\end{aligned}
$$

The mixing-cell cascade model provides results equivalent to the one-dimensional, convective-dispersion equation with varying values of the dispersion coefficient. ${ }^{3}$ In the limit, as $N$ tends to infinity, the model represents flow through a system with zero dispersion, whereas for $\mathrm{N}$ equal to one, the model represents flow with an infinite dispersion coefficient.

\section{MODELS}

The ERDF design calls for a trench approximately $300 \mathrm{~m}$ wide and $21 \mathrm{~m}$ deep. The trench is intended to be built in a modular fashion (i.e., expanded as needed) up to a maximum length of approximately $2740 \mathrm{~m}$. The trench will slope up on the sides and ends, making the surface dimensions somewhat larger (approximately $430 \mathrm{~m}$ by $2870 \mathrm{~m}$ ). The ERDF, if expanded to its maximum size, will be capable of holding almost $22,000,000 \mathrm{~m}^{3}$ of waste (mostly in the form of contaminated soils). The long axis of the facility will be oriented east-west, which is parallel to the aquifer flow beneath the site.

The ERDF was modeled using a three-dimensional, rectangular-mesh geometry. The aquifer was modeled with the direction of flow as the axis and depth as the $Y$ axis. The $Z$ axis (perpendicular to the aquifer flow) was represented by two planes, $1 \mathrm{~m}$ apart, with reflective boundaries, which effectively modeled an infinitely wide trench. The downstream end of the trench was modeled along with $150 \mathrm{~m}$ of trench upstream (see Figure 1). The exact length of the trench was treated as arbitrary after preliminary calculations demonstrated that the peak concentrations predicted for these trenches are relatively independent of the distribution of the waste parallel to the aquifer flow (assuming a fixed inventory). The bulk of the model is 
made up of $5-\mathrm{m}$ by $5-\mathrm{m}$ mesh. In the vicinity of the 1 iner, the height of the elements is gradually reduced to $1 \mathrm{~m}$. Along the sloped side of the trench, $0.5-\mathrm{m}$ by $0.5-\mathrm{m}$ mesh is used for a more accurate representation of the slope. VAM3DCG does have the capability of using nonorthogonal mesh, so the slope could have been modeled explicitly. There is, however, an error proportional to the degree of nonorthogonality, and when the technique was tried for this case, the calculated velocity field had significant horizontal gradients in it. Therefore, standard rectangular mesh, arranged in a stair-step fashion, is used to model the slope.

A number of parameters are needed to model the vadose-zone hydrology and transport from the ERDF site. The rate at which water can travel through the vadose zone is extremely sensitive to the moisture content of the sediment. Important parameters that characterize the vadose-zone hydrology are the moisture retention characteristics and the unsaturated hydraulic conductivities of the soils and sediments within the vadose zone.

Construction of a model to represent the vadose zone and the unconfined aquifer beneath the ERDF site was limited by the scale of geologic heterogeneity and the amount of geohydrologic data available to distinguish the stratigraphic units and subunits from each other. There are two major units beneath the ERDF site, the Hanford and the Ringold, and several subunits. The selected model used five material layers, in addition to the facility liner. Layer thicknesses and hydrologic properties were based on the lithologic description derived from continuous cores taken from boreholes within the ERDF site and adjacent sites. The water table beneath the ERDF site is at $97 \mathrm{~m}$, with a thickness of slightly over $30 \mathrm{~m}$. Although the exact depth of the bottom of the unconfined aquifer was estimated, this uncertainty has little consequence in the analysis because there is little vertical dispersion in the aquifer over the range of interest.

The use of layer-cake stratigraphy was justified by the observation that variation in thickness is not extreme for any of the units considered in the analysis. In addition, a sensitivity study was performed to evaluate the significance of variability in vadose-zone permeabilities and thicknesses by doing a comparative analysis in which the most permeable unit was assumed to exist throughout the vadose zone. This analysis supported the contention that radionuclide concentration estimates are not highly sensitive to these kinds of parameter variabilities.

In spite of the relative consistency of the stratigraphic units, there are anomalies that could pose problems. Vertical features referred to as clastic dikes occur sporadically in the Hanford formation and have been observed in the ERDF site. The dikes are quite variable in size and makeup. Typically the cross-sectional area is small $\left(<1 \mathrm{~m}^{2}\right)$. No permeability information is available, but the dikes potentially could be filled with high permeability material. Because of the small volume of these dikes and the low frequency of occurrence, however, it is expected that they will have little impact on the flux of contaminants. To confirm this, a sensitivity analysis was performed to evaluate the potential impact of these dikes. A total of five moisture-characteristic curves, representing the five subunits and two materials for the liner, were used for the simulations. The five formation types (four Hanford sediment layers, and Ringold "E" gravel) and the liner materials (clean gravel and clay) are referred to as material types 1 through 7 , respectively (see Table 1 ). The laboratory-measured ${ }^{4}$ moisture retention data were fitted with the van Genuchten model using the computer code RETC. ${ }^{5}$ All unsaturated conductivity estimates are based on the Mualem predictive model, laboratory-measured 
saturated conductivity, and the fitted moisture retention curve. Additional boreholes have recently been drilled at the ERDF site and unsaturated conductivity experiments will be performed on the borehole samples. These additional data, along with moisture-retention data for samples collected from boreholes drilled recently at the site, will allow us to check on the accuracy of our predicted values.

The ERDF trenches will be lined with a barrier constructed of a layer of gravel over a layer of clay. This liner is intended to add an additional layer of protection against release of contaminants to the groundwater in the event of higher infiltration rates. Because this liner is thin and has material properties that are considerably different from the surrounding soil types, it adds a great deal to the computational complexity (and therefore cost) of the modeling effort. As long as the trench cover is in place or the infiltration rate remains otherwise low however, the liner should have only a small effect. Furthermore, omitting the liner from the model is a conservative assumption and simulates the possibility of a mechanical failure in the liner. For these reasons the base case was run both with and without the liner, for comparison, and the other sensitivity studies were run without the liner in the model.

Table 1. Hydraulic Properties for the ERDF Model.

\begin{tabular}{|c|c|c|c|c|c|c|c|c|c|}
\hline $\begin{array}{c}\text { Sample } \\
\text { depth }\end{array}$ & $\begin{array}{c}\text { Formation } \\
\text { type }\end{array}$ & $\begin{array}{c}\text { Material } \\
\text { number }\end{array}$ & $\begin{array}{c}\text { Depth } \\
(\mathrm{m})\end{array}$ & $\theta_{\mathrm{s}}$ & $\Theta_{\mathrm{r}}$ & $\alpha(1 / \mathrm{m})$ & $\mathrm{n}$ & $\mathrm{K}_{\mathrm{s}}(\mathrm{m} / \mathrm{yr})$ & $\rho_{\mathrm{b}}\left(\mathrm{g} / \mathrm{cm}^{3}\right)$ \\
\hline $45^{\prime}$ & $\begin{array}{l}\text { Hanford } \\
\text { sediments }\end{array}$ & $(1)$ & 0.00 & 0.3419 & 0.039 & 2.88 & 2.2829 & 1,675 & 1.57 \\
$70^{\prime}$ & $\begin{array}{l}\text { Hanford } \\
\text { sediments }\end{array}$ & $(2)$ & 6.00 & 0.4412 & 0.048 & 1.440 & 5.3741 & 495 & 1.52 \\
$45^{\prime}$ & $\begin{array}{l}\text { Hanford } \\
\text { sediments }\end{array}$ & $(3)$ & 9.00 & 0.3419 & 0.039 & 2.88 & 2.2829 & 1,675 & 1.57 \\
190 & $\begin{array}{l}\text { Hanford } \\
\text { sediments }\end{array}$ & $(4)$ & 21.00 & 0.4547 & 0.023 & 4.740 & 2.8501 & 1,823 & 1.56 \\
300, & $\begin{array}{l}\text { Ringold "E" } \\
\text { gravel }\end{array}$ & $(5)$ & 88.00 & 0.1208 & 0.00 & 1.140 & 1.4499 & 22,960 & 1.64 \\
N/A & $\begin{array}{l}\text { Clean gravel } \\
\text { (liner) }\end{array}$ & $(6)$ & 19.00 & 0.5180 & 0.014 & 353.7 & 2.6610 & 583,400 & 1.38 \\
N/A & $\begin{array}{l}\text { RCRA clay } \\
\text { (liner) }\end{array}$ & (7) & 22.00 & 0.4480 & 0.00 & 0.0539 & 1.3240 & 315.4 & 1.50 \\
\hline
\end{tabular}

Sorption and desorption reactions that control the distribution of radionuclides between water and solid will have a significant impact on the peak concentrations in groundwater. Typically, the distribution is quantified by a sorption coefficient, or $\mathrm{Kd}(\mathrm{mL} / \mathrm{g})$, whose value increases as the relative fraction of radionuclide increases on the solid phases. Exact values for $\mathrm{Kd}$ are difficult to determine, so in order to be conservative, 0.0 is typically used. A parametric study was performed, however, to evaluate the impact of a higher Kd.

The driving force behind the transport to the groundwater is the recharge from precipitation. The recharge is the difference between site-specific precipitation and evaporation, transpiration, and runoff. Lysimeter studies ${ }^{6}$ have been used to 
evaluate Hanford Site recharge processes. Because the texture of sediments and the degree of vegetation can have profound effects on the movement of water, the estimate of recharge at a specific site is usually associated with high uncertainty. For the purposes of this study, it was assumed that a cover would be constructed over the ERDF site that would limit recharge to $0.005 \mathrm{~m} / \mathrm{yr}$.

The contaminant source term for the ERDF trench was modeled as $1.0 \mathrm{C} i$ of waste distributed evenly throughout the trench. The $1.0 \mathrm{Ci}$ amount was chosen arbitrarily based on the assumption that the peak concentration in the groundwater is directly proportional to the inventory (i.e., it is scalable). Parametric studies have born out this assumption. A release rate from the trench was calculated based on a mixing cell cascade algorithm, as discussed previously. The resulting release rate, for a typical node in the bottom of the trench, is shown in Figure 2 . This release rate was used as an input to the VAM3DCG calculations.

In addition to the advection-dominated release, a solubility-dominated release model was used. In this case the concentration was constant over time to represent isotopes (such as uranium) that have a maximum concentration less than that

predicted by the advection-dominated model. A concentration of $1.0 \mathrm{Ci} / \mathrm{m}^{3}$ was used, again on the assumption that it was scalable.

\section{RESULTS}

The results of the groundwater analyses for the ERDF are presented in this section. The primary results of these analyses are the maximum concentrations in the well and the times at which they occur. These results are summarized, for all of the cases, in Table 2.

\section{A. Base Case}

The release and transport results for the base case ERDF model are shown in Figures 3 and 4 . Figure 3 shows the change in the contaminant plume over time. Four different times were chosen to show a characteristic progression. Some significant aspects of the soil column hydrologic characteristics can also be seen in Figure 3. First, moderate dispersion is seen in the analysis, as shown by the slight horizontal spreading of the plume beyond the vertical boundaries of the trench until the plume reaches the aquifer and the minimal vertical spreading of the plume in the aquifer. Second, the right-angle shape of the plume clearly demonstrates the change in direction of flow from vertical to horizontal in the vadose zone and the unconfined aquifer. Third, the concentration contour lines show a significant increase in dilution of contaminant concentration brought about by mixing vadose-bearing water with fresh water in the unconfined aquifer. Figure 4 shows the peak concentration in the downstream we11.

\section{B. Effects of the Liner}

The base case was also run with no 1 iner. The general shape of the resulting concentration curve was essentially the same, but the peak increased by about $8 \%$ and occurred slightly earlier. Several other liner/no liner comparisons were made, and the difference was found to be the same or smaller. The only exception was in the high $\mathrm{Kd}$ case. In this case, the absence of a liner resulted in an increase in peak concentration of approximately $22 \%$. For the most part, however, the effect of omitting the 1 iner was smal1, and in all cases it was conservative, so the liner was omitted from the remaining cases. 
Table 2. Peak Concentrations.

\begin{tabular}{|c|c|c|c|}
\hline Run number & Kd & $\begin{array}{l}\text { Peak concentration } \\
\left(\mathrm{C} i / \mathrm{m}^{3}\right)\end{array}$ & $\begin{array}{l}\text { Time to peak } \\
\text { concentration } \\
\text { (yrs) }\end{array}$ \\
\hline \multicolumn{4}{|c|}{ Liner, advection-dominated release } \\
\hline $1 \mathrm{a}$ & 0 & $2.49 \mathrm{E}-6$ & 900 \\
\hline $1 b$ & 1 & $1.31 \mathrm{E}-7$ & 19,800 \\
\hline $1 c$ & 10 & $1.23 \mathrm{E}-8$ & 191,800 \\
\hline \multicolumn{4}{|c|}{ No-liner, advection-dominated release } \\
\hline $2 a$ & 0 & $2.68 E-6$ & 822 \\
\hline $2 b$ & 1 & $1.36 \mathrm{E}-7$ & 19,300 \\
\hline $2 c$ & 10 & $1.50 \mathrm{E}-8$ & 186,000 \\
\hline \multicolumn{4}{|c|}{ Constant concentration release, 1 iner, $95 \%$ of maximum concentration } \\
\hline $1 \mathrm{a}-\mathrm{cc}$ & 0 & $2.96 \mathrm{E}-3$ & 970 \\
\hline \multicolumn{4}{|c|}{ Constant concentration release, no- 1 iner, $95 \%$ of maximum concentrati } \\
\hline $2 a-c c$ & 0 & $3.07 \mathrm{E}-3$ & 895 \\
\hline \multicolumn{4}{|c|}{ Clastic dike } \\
\hline $3 a$ & 0 & $2.68 \mathrm{E}-6$ & 825 \\
\hline \multicolumn{4}{|l|}{ Hot spot } \\
\hline $4 a$ & 0 & $3.07 \mathrm{E}-6$ & 930 \\
\hline
\end{tabular}




\section{Effects of Varying Kd}

The base case analyses assumed a Kd value of 0.0. In fact, however, different radionuclides will have different Kd values. In order to quantify how this variation in $\mathrm{Kd}$ will affect the peak concentration values, a parametric study was performed on the Kd value.

The $\mathrm{Kd}$ values considered were 0,1 , and $10 \mathrm{~mL} / \mathrm{g}$, representing radionuclides that are nonsorbing, weakly sorbing, and moderately or strongly sorbing, respectively. Although the shapes of the resulting concentration curves are identical, the time over which the plume occurs shifts farther into the future with increasing Kd value, reflecting the increasing retardation of transport relative to groundwater flux with increasing reactivity between the radionuclide and the soil. Similarly, as the time of transport is increased and larger quantities of water interact with the radionuclide over time, a reduction in groundwater concentration occurs. It is important to note that both peak times and concentrations are essentially (inversely) proportional to the change in Kd value (more precisely, the proportionality is related to the retardation coefficient, which is unity when $\mathrm{Kd}=0$, about 16 at $\mathrm{Kd}=1$, and about 150 at $\mathrm{Kd}=10)$.

\section{Effects of Clastic Dikes}

It is expected that the truncated nature and limited volume of clastic dikes will prevent them from being major conduits for enhanced contaminant transfer to the unconfined aquifer. To test this hypothesis, a conservative analysis was conducted in which a dike was placed directly underneath the trench at the 150-m mark. The dike was $1 \mathrm{~m}$ wide and extended down through the Hanford sediment. The dike was represented as a zone of high-permeability material. To reduce the calculational complexity, this case was modeled without a liner. The clastic dike case produced a peak concentration of $2.68 \times 10^{-6} \mathrm{Ci} / \mathrm{m}^{3}$ at 825 years. This is essentially identical to the results of the no-liner case, indicating that the presence of clastic dikes is of little significance.

\section{E. Effects of Waste Concentration}

An additional concern was the possibility of some of the waste being concentrated in one area rather than being distributed over the length of the trench. To evaluate the potential effect of this, an extreme case was analyzed in which the entire inventory was concentrated over one node of the trench model. This resulted in an increase of $15 \%$ over the base case.

\section{REFERENCES}

1. DOE, 1988, Radioactive Waste Management, DOE Order 5820.2A, U.S. Department of Energy, Washington D.C.

2. Huyakorn, P. S., and Sorab Panday, 1994, VAM3DCG: A Variab7y Saturated Analysis Model in Three-Dimensions with Preconditioned Conjugate Gradient Matrix Solvers - Documentation and User's Guide, Version 3.1, HydroGeologic, Incorporated, Herndon, Virginia.

3. Kozak, M. W., M. S. Chu, T. A. Mattingly, J. D. Johnson, and J. T. McCord, 1990, Background Information for the Development of a Low-Level Waste Performance Assessment Methodology, NUREG/CR-5453, SAND90-0375, Vo1. 5. 
4. Bergeron, M. P., G. V. Last, and A. E. Reisenauer, 1987, Geohydrology of a Commercial Low-Level Radioactive Waste Disposal Facility Near Richland, Washington, Pacific Northwest Laboratories, Richland, Washington.

5. van Genuchten, M. Th., F. J. Leij, and S. R. Yates, 1991, The RETC Code for Quantifying the Hydraulic Functions of Unsaturated Soils, EPA/000/0-91/000, U.S. Environmental Protection Agency, Washington D.C.

6. Gee, G. W. and R. R. Kirkham, 1984, Arid Site Water Balance-

Evapotranspiration Mode7ing and Measurements, PNL-5177, Pacific Northwest Laboratory, Richland, Washington.

Figure 1. Model Geometry.

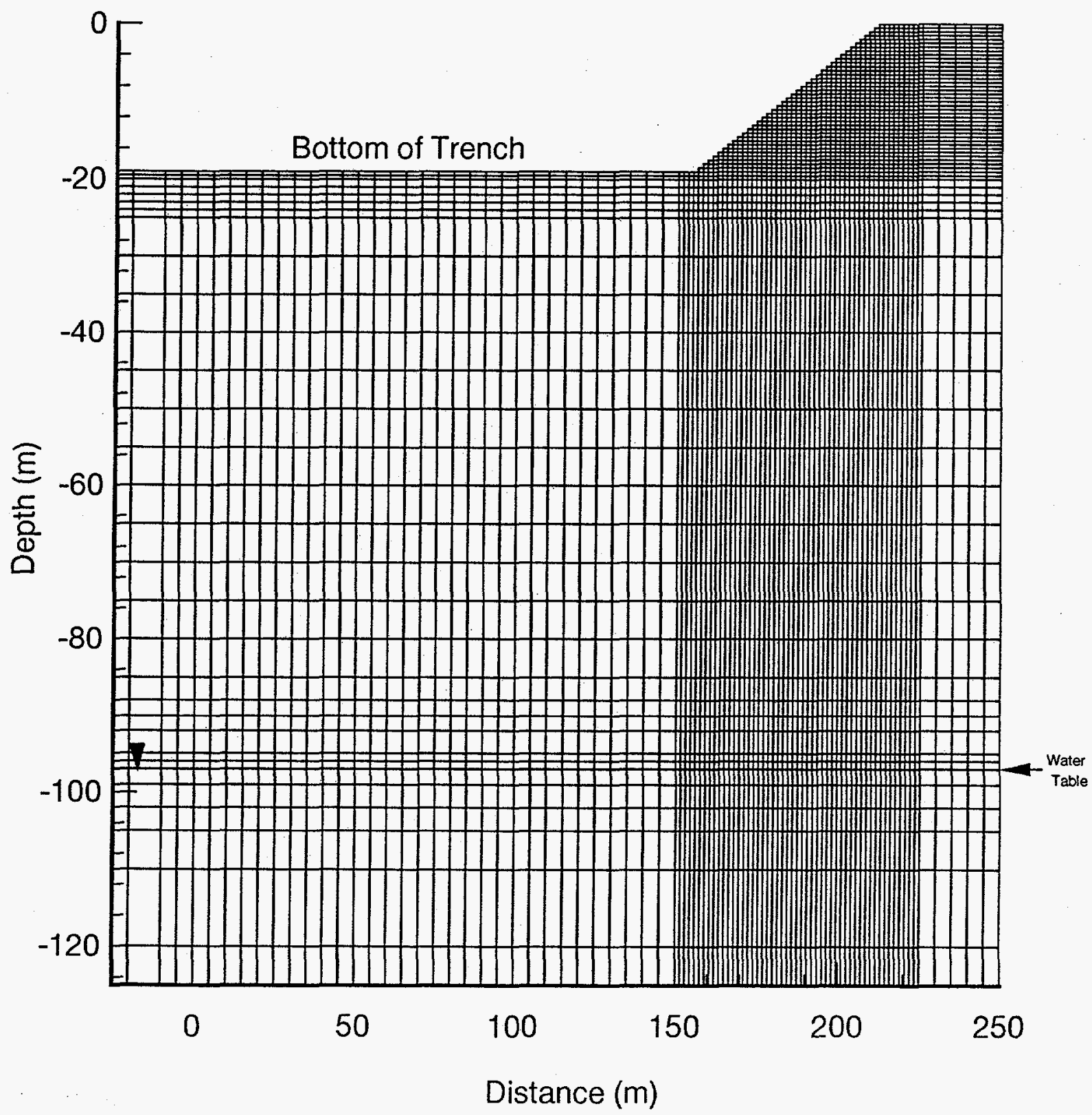


Figure 2. Release Rate at Bottom of Trench.

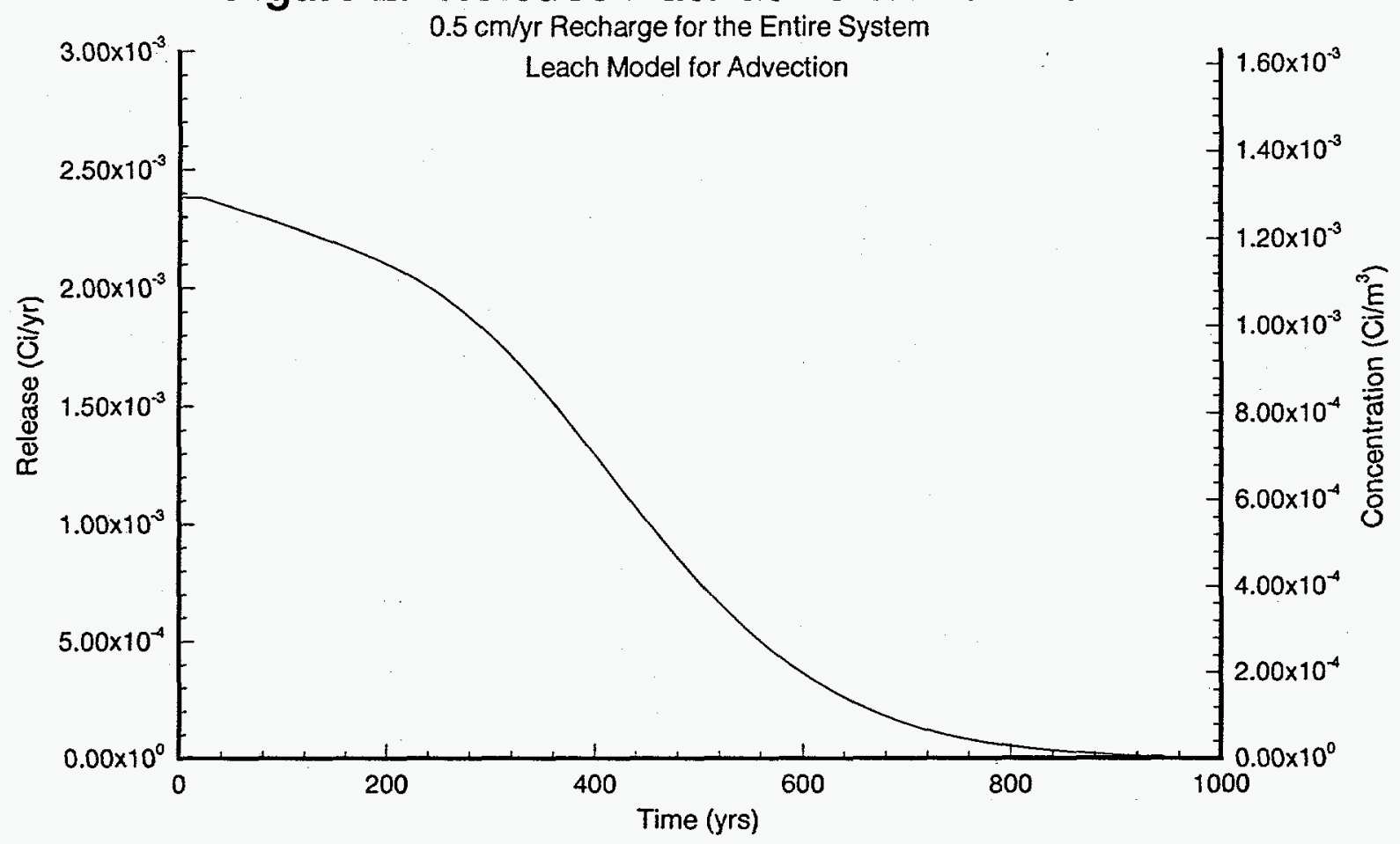

Figure 3. Peak Concentration At The Well.

$K_{d}=0$, advection-dominated release, liner, recharge $=0.5 \mathrm{~cm} / \mathrm{yr}$

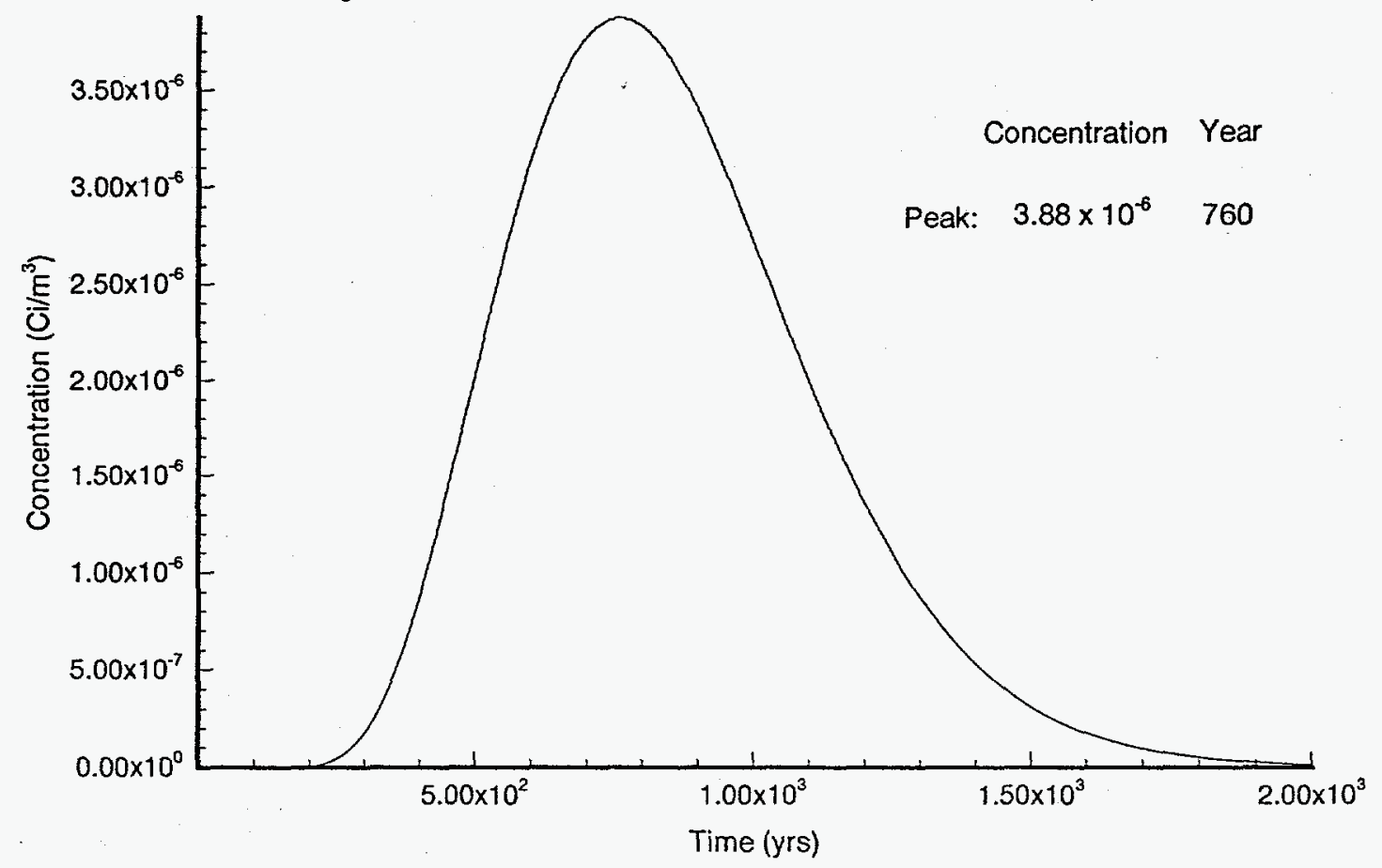




\section{Figure 4. Concentration at Various Times.}

\section{$\mathrm{K}_{\mathrm{d}}=0$, advection-dominated release, liner, recharge $=0.5 \mathrm{~cm} / \mathrm{yr}$}

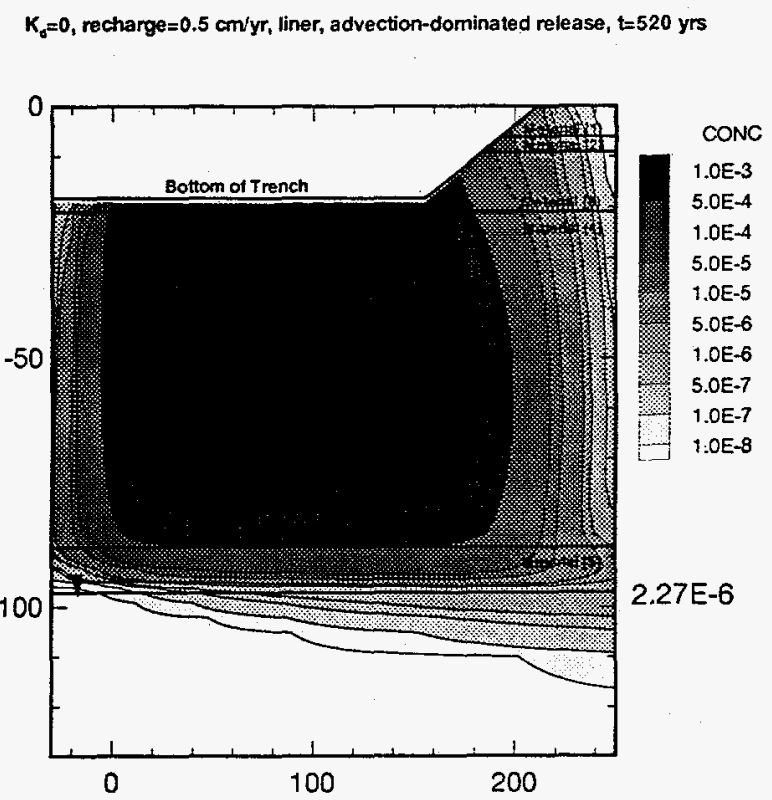

$K_{d}=0$, recharge $=0.5 \mathrm{~cm} / \mathrm{yr}$, liner, advection-dominated release, $t=1000$ yrs

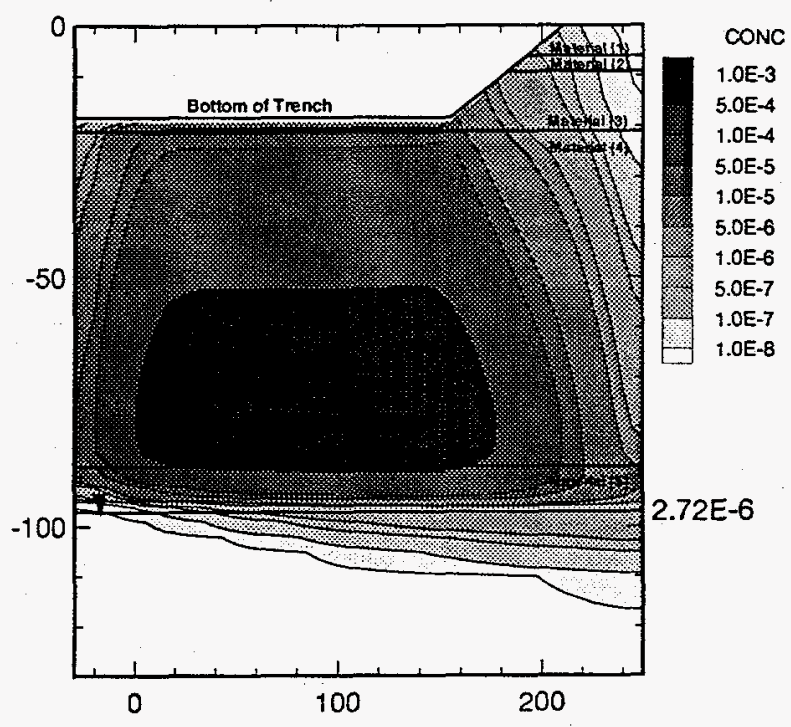

$K_{6}=0$, recharge $=0.5 \mathrm{~cm} / \mathrm{yr}$, tiner, advection-dominated release, $t=1520$ yrs

$K_{d}=0$, recharge $=0.5 \mathrm{~cm} / y r$, liner, advection-dominated release, $t=2000 \mathrm{yrs}$
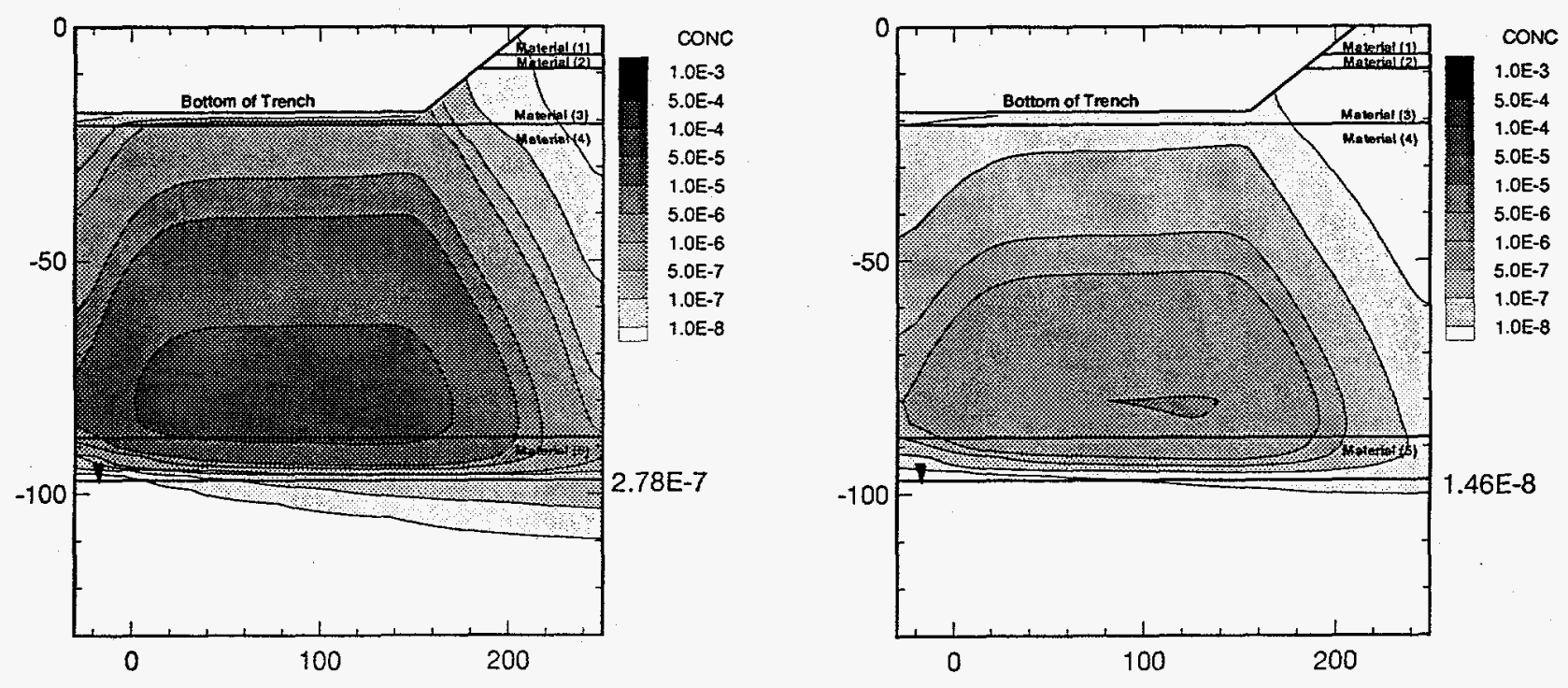